\title{
Penerapan Teknologi Jarwo Super pada Usahatani Padi Sawah di Kabupaten Pesawaran Provinsi Lampung
}

\author{
Application of Jarwo Super Technology to Rice Farming in Pesawaran District, \\ Lampung Province
}

\author{
Oleh: \\ Slameto $^{1 *}$, Agung Lasmono ${ }^{\text {* }}$ \\ ${ }^{1}$ Balai Pengkajian Teknologi Pertanian Lampung \\ J1. Hi. Zainal Abidin Pagar Alam No.1A, Rajabasa, Bandar Lampung 35145 \\ *E-mail: islameto@yahoo.co.id, bptplasmono@gmail.com
}

Received January 18, 2020; Revised June 15, 2020; Accepted June 27, 2020

\begin{abstract}
ABSTRAK
Pemerintah terus berupaya meningkatkan produksi pangan khususnya beras melalui penciptaan inovasi teknologi. Salah satu inovasi dari Badan Litbang Pertanian adalah teknologi Jarwo Super. Tujuan penelitian ini adalah menganalisis penerapan teknologi Jarwo Super pada usahatani padi sawah di Kabupaten Pesawaran, Lampung. Metode kajian berupa observasi terhadap bagian pelaksanaan program penerapan inovasi teknologi Jarwo Super 1000 ha tahun 2017. Lokasi kajian sesuai dengan program pengembangan Jarwo Super (200 ha) di sentra produksi padi sawah di Kabupaten Pesawaran, Lampung. Waktu penelitian pada musim tanam kedua (Juli-Agustus s/d Nopember-Desember) tahun 2017. Data yang diamati meliputi keragaan produksi padi dan tanggapan para petani terhadap inovasi Jarwo Super. Analisis dilakukan secara deskriptif. Hasil kajian menunjukkan implementasi teknologi Jarwo Super masih memberikan hasil produksi padi yang cukup bervariasi 4-8 ton/ha dengan rata-rata 6,5 ton/ha. Tanggapan petani bahwa kebaharuan inovasi berupa adanya penekanan penggunaan saprodi bersifat organik (biodekomposer, pestisida nabati, pupuk organik). Menurut petani apabila diterapkan sesuai prosedur maka inovasi teknologi jajar legowo super sangat prospektif meningkatkan produksi dan pendapatan usahatani padi.
\end{abstract}

Kata Kunci: inovasi teknologi, jarwo super, padi sawah, produksi

\begin{abstract}
ABSTRAK
The government continues to increase food production, especially rice, through the creation of technological innovations. Jarwo Super is one of innovation generated by The Indonesian Agency for Agricultural Research and Development. The current study aimed to analyze Jarwo Super technology implementation on rice farming in Pesawaran regency, Lampung. The methodology was performed by observation towards components of Jarwo Super 1000 technology in 2017. The study was located in the Jarwo Super development area of the rice production center in Pesawaran regency, Lampung covering 200 hectares. The time of research was in the second planting season (from July to August and from November to December) in 2017. Observed data included the performance of rice production, and farmers' responses to Jarwo Super innovations were analyzed descriptively. The result of the study showed that Jarwo Super implementation produced various rice production of 4-8 tons/ ha with an average of 6,5 tons/ ha. The farmers' response that the renewal of innovations is in the form of emphasis on the use of organic inputs (bio decomposers, vegetable pesticide, and organic fertilizers). According to the farmers, if the components are applied according to the procedure, the Jarwo Super is very prospective in increasing rice farming production and income.
\end{abstract}

Keywords: technological innovation, jarwo super, rice fields, production 


\section{PENDAHULUAN}

Target peningkatan produksi padi di Lampung Tahun 2015-2017 sebesar 1 juta ton GKG. Luas baku sawah di Lampung tahun 2017 seluas 369.362 ha, target luas panen tahun tersebut 833.886 ha dengan target produksi sebanyak 4.401 .188 ton atau produktivitas mencapai 5,278 ton/ha gabah kering giling (Dinas Pertanian Tanaman Pangan dan Hortikultura Propinsi Lampung, 2017). Upaya yang dilakukan selama ini antara lain melalui peningkatkan luas areal tanam padi dan peningkatan produktivitas tanaman.

Adapun perubahan iklim, keterbatasan infrastruktur dan sarana-prasarana pendukung produksi pertanian merupakan tantangan yang perlu dihadapi dan disiasati pemecahannya. Program pemerintah yang terus memacu produksi pangan khususnya komoditas beras tersebut mendorong penciptaan inovasi teknologi pengungkit produksi padi. Salah satu inovasi dari Badan Litbang Pertanian untuk upaya peningkatan produktivitas melalui penerapan teknologi spesifik lokasi yaitu inovasi teknologi Jajar Legowo Super (Jarwo Super). Salah satu keunggulan teknologi tersebut adalah mampu mendorong mempercepat untuk menanam padi kembali setelah panen.

Menurut Badan Litbang Pertanian (2016a), Jarwo Super merupakan sistem produksi padi yang mengimplementasikan secara terpadu teknologi budidaya padi inovasi dari Badan Litbang Pertanian berbasis cara tanam jajar legowo. Jajar Legowo merupakan sistem tanam pindah dimana antara 2 atau 4 barisan tanaman padi terdapat lorong kosong memanjang sejajar dengan barisan tanaman padi, sedangkan dalam barisan menjadi setengah atau lebih jarak tanam dalam baris. Merupakan implementasi terpadu teknologi budidaya padi dengan lima komponen teknologi pelengkap. Berbasis sistem tanam jajar legowo maka lima komponen teknologi tersebut berupa: (a) pemanfaatan varietas unggul baru (VUB) padi dengan potensi hasil yang tinggi, (b) penggunaan biodekomposer, (c) penggunaan pupuk hayati, (d) pengendalian organisme pengganggu tanaman dengan penggunaan pestisida nabati dan anorganik, serta (e) pemanfaatan alat mesin pertanian khususnya mesin penanam (transplanter) dan mesin pemanen (combine harvester).

Penggunaan bahan biodekomposer yang merupakan bahan yang mengandung beberapa jenis mikroba perombak bahan organik sisa tanaman seperti lignoselulosa. Biodekomposer mampu mempercepat pengomposan jerami secara insitu dari dua bulan menjadi 1-2 minggu. Hasil aplikasi dari biodekomposer mempercepat perombakan jerami dan mengubah residu organik menjadi bahan organik tanah, meningkatkan ketersediaan unsur Nitrogen Phospor Kalium, sehingga menekan biaya pemupukan, dan menekan penyakit tular tanah (Badan Litbang Pertanian, 2016a).

Penggunaan pupuk hayati dan pemupukan berimbang berdasarkan PUTS (perangkat uji tanah sawah) juga menjadi komponen pada jarwo super. Pupuk hayati adalah pupuk berbasis gabungan mikroba mikroba non patogenik yang dapat menghasilkan fitohormon (pemacu tumbuh tanaman), penambat Nitrogen dan pelarut Fosfat yang berfungsi meningkatkan kesuburan dan kesehatan tanah (Badan Litbang Pertanian, 2016a).

Hasil penelitian Badan Litbang Pertanian menunjukkan bahwa berdasarkan hasil panen ubinan yang dilakukan oleh Tim terpadu BPS Indramayu, Peneliti Balitbangtan, Badan Ketahanan Pangan dan Penyuluhan Pertanian Indramayu, UPTD Kecamatan Bangodua, TNI dari Koramil Bangodua, dan beberapa Gapoktan di Indramayu, diperoleh produktivitas Gabah Kering Panen (GKP) di dem-area seluas 50 ha (Badan Litbang Pertanian, 2016b).

Melalui Penerapan Teknologi Jarwo Super untuk produktivitas padi varietas Inpari 30 Ciherang Sub-1 sebesar 13,9 t/ha; Varietas Inpari 32 HDB sebesar 14,4 t/ha; dan Varietas Inpari 33 sebesar 12,4 t/ha, 
sedangkan rata-rata produktivitas pertanaman petani di luar dem-area dengan varietas Ciherang hanya sebesar 7,0 t/ha (Badan Litbang Pertanian, 2016b).

Petani yang menerapkan paket teknologi ini secara penuh bisa mendapatkan produksi sekitar 10 ton Gabah Kering Giling (GKG)/ha per musim tanam dengan kata lain ada penambahan produksi sebesar 4 ton GKG/ha per musim tanam dibandingkan dengan rata-rata produksi Jajar Legowo biasa yang di terapkan di sawah irigasi sebesar 6 ton $/ \mathrm{ha} /$ musim (Badan Litbang Pertanian, 2016b).

Sehingga pada Tahun 2017 melalui program dari Kementerian Pertanian pengembangan inovasi teknologi Jarwo Super tersebut dilakukan untuk mengantisipasi semakin menyusutnya lahan pertanian, sementara permintaan komoditas pangan khususnya beras terus meningkat. Hasil analisis menunjukkan apabila inovasi teknologi Jarwo Super ini dikembangkan di $20 \%$ dari total lahan pertanian irigasi saja, maka dapat menyumbang kenaikan produksi 3,84 juta ton Gabah Kering Giling (GKG) pertahun. Sehingga mengawali program tersebut pada tahun 2017 di Lampung mendapatkan alokasi seluas 1000 ha lahan sawah untuk diimplementasikan teknologi Jarwo Super. Salah satunya adalah Kabupaten Pesawaran, Propinsi Lampung.

Namun pada proses implementasinya akan berbeda bergantung pada kondisi spesifik wilayah tertentu. Untuk itu tujuan penelitian ini adalah menganalisis penerapan teknologi Jarwo Super pada usahatani padi sawah di Kabupaten Pesawaran Provinsi Lampung.

\section{METODE PENELITIAN}

Metode kajian berupa observasi lapangan dilanjutkan dengan survei terhadap implementasi program penerapan inovasi teknologi Jajar Legowo Super (Jarwo Super) 1000 ha di Lampung tahun 2017. Pada kajian ini lokasi pada sentra produksi padi sawah di Kabupaten
Pesawaran, Lampung, dimana penerapan inovasi teknologi Jarwo Super mendapat alokasi seluas 200 ha.

Di Kabupaten Pesawaran, Jarwo Super dicoba terapkan oleh 12 kelompok tani yang melibatkan sekitar 313 petani padi sawah. Tersebar di 10 desa pada 6 Kecamatan meliputi: Kecamatan Gedong Tataan (Desa Bagelen dan Kutoarjo), Kecamatan Way Khilau (Desa Sukajaya dan Padang Cermin), Kecamatan Kedondong (Desa Tebajawa), Kecamatan Way Lima (Desa Banjarnegeri), Kecamatan Padang Cermin (Desa Trimulyo dan Padang Cermin), Kecamatan Way Ratai (Desa Ceringin Asri dan Kalirejo). Implementasi inovasi teknologi jarwo super diawali dengan pemberian paket bantuan bibit padi varietas unggul baru sebanyak $25 \mathrm{~kg} / \mathrm{ha}$ (varietas Inpari 30, atau Inpari 32), Pupuk hayati berupa Agrimeth $400 \mathrm{gr} / \mathrm{ha}$ (10 bungkus/ha dengan kemasan 40 gr/bks), dekomposer M-Dec $2 \mathrm{~kg} / \mathrm{ha}$ (4 bks/ha kemasan $500 \mathrm{gr} / \mathrm{bks}$ ), pupuk Urea 150 $\mathrm{kg} / \mathrm{ha}$, pupuk NPK Phonska $200 \mathrm{~kg} / \mathrm{ha}$ dan bantuan tanam Rp.400.000,- per ha.

Waktu penelitian pada musim tanam kedua (Juli-Agustus s/d NopemberDesember) tahun 2017. Data yang diamati meliputi implementasi teknologi Jarwo Super, produksi padi, pendapatan petani dan pengetahuan serta tanggapan petani terhadap inovasi teknologi Jarwo Super. Analisis data dan penyajian dilakukan secara statistik deskriptif (Nazir, 2005).

\section{HASIL DAN PEMBAHASAN}

\section{Karakteristik Petani Padi}

Karakteristik petani padi sawah di Pesawaran dari hasil survei didapatkan informasi bahwa usia rata-rata petani 48,3 tahun yang berarti masih usia produktif angkatan kerja. Diharapkan umur yang cenderung produktif mampu mempengaruhi daya tangkap dan keberhasilan dalam pembelajaran (Pailis, (2006); Matualage (2010); Utami (2009); Mc.Elreath (2004)) sehingga usahatani berhasil. Sebagian besar 
petani mempunyai tingkat pendidikan sekolah lanjutan tingkat pertama yang berarti cukup cakap dalam menerima informasi dan memenuhi wajib belajar sembilan tahun. Menurut Subin et al. (2007) bahwa tingkat pendidikan semakin tinggi maka seseorang akan semakin inovatif. Meskipun para petani relatif masih berada pada jenjang pendidikan lanjutan pertama diharapkan dalam hal ini dengan kombinasi umur yang relatif masih muda juga tetap inovatif.

Tabel 1.

Karakteristik Petani Padi Sawah di Pesawaran, Lampung Tahun 2017

\begin{tabular}{llc}
\hline No & Karakteristik & Nilai \\
\hline 1. & Usia rata-rata (tahun) & 48,3 \\
2. & Pendidikan: & \\
& - Lulus SD (\%) & 10 \\
& - Lulus SLTP (\%) & 70 \\
& $\quad$ - SLTA (\%) & 20 \\
3. & Pengalaman bertani (tahun) & \\
4. Pekerjaan bertani (\%) & 100 \\
5. Pekerjaan sambilan sebagai $\quad$ Buruh & 50 \\
& (\%) & \\
6. Jumlah tanggungan keluarga & rata-rata & 2 \\
& (orang) & \\
\hline
\end{tabular}

Sumber: data primer petani padi (diolah), 2017.

Sedangkan untuk pengalaman dalam bidang bertani rata-rata para petani telah berpengalaman (23 tahun). Sehingga dimungkinkan petani telah mempunyai keyakinan kemampuan diri yang tinggi dan berani dalam mengambil risiko sehingga lebih mudah dalam menerima inovasi teknologi baru.

\section{Penerapan Teknologi Jarwo Super}

Hasil observasi serta wawancara terhadap petani di lapangan menunjukkan bahwa implementasi komponen teknologi jarwo super di wilayah Pesawaran seperti diperlihatkan pada Tabel 2. Pada tabel tersebut terlihat bahwa belum semua petani melakukan kegiatan usahatani padi sawah dengan cara teknologi seutuhnya sesuai rekomendasi (full technology).

Beberapa petani masih menerapkan teknologi sesuai kebiasaanya. Bahkan pada penggunaan pupuk hayati $(20 \%)$ dan pupuk kandang sebagian besar petani (70\%) belum dilaksanakan. Dalam penggunaan biodekomposer, masih ada beberapa petani (10\%) yang belum menggunakan. Penanaman dengan sistem jajar legowo juga belum dilaksanakan oleh sebagain kecil petani di kabupaten pesawara. Hasil penelitian memberikan informasi bahwa terdapat sekitar $10 \%$ petani yang belum melakukan penanaman padi sistem tanam jarwo super.

Tabel 2.

Penerapan Inovasi Jarwo Super di Pesawaran, Lampung Tahun 2017

\begin{tabular}{|c|c|c|}
\hline No. & $\begin{array}{lll}\text { Beberapa Komponen } & \text { Inovasi } \\
\text { Jarwo Super } & \\
\end{array}$ & $\begin{array}{c}\text { Prosentase } \\
(\%)\end{array}$ \\
\hline 1. & $\begin{array}{l}\text { Penggunaan Varietas Unggul: } \\
\text {-VUB Inbrida }(\%) \\
\text {-VUB Hibrida }(\%)\end{array}$ & $\begin{array}{c}100 \\
0\end{array}$ \\
\hline 2. & $\begin{array}{l}\text { Cara persemaian: } \\
\text {-Dapok }(\%) \\
\text {-Bukan dapok }(\%)\end{array}$ & $\begin{array}{l}70 \\
30\end{array}$ \\
\hline 3. & $\begin{array}{l}\text { Penggunaan pupuk hayati: } \\
\text {-Ya menggunakan Agrimeth (\%) } \\
\text {-Tidak menggunakan }(\%) \\
\text {-Lainnya }(\%)\end{array}$ & $\begin{array}{c}80 \\
20 \\
0\end{array}$ \\
\hline 4. & $\begin{array}{l}\text { Penggunaan pupuk kandang/ } \\
\text { kompos: } \\
\text {-Ya menggunakan }(\%) \\
\text {-Tidak menggunakan }(\%)\end{array}$ & $\begin{array}{l}30 \\
70\end{array}$ \\
\hline 5. & $\begin{array}{l}\text { Penggunaan dekomposer: } \\
\text {-Ya menggunakan M-Dec(\%) } \\
\text {-Tidak menggunakan }(\%) \\
\text {-Lainnya }(\%)\end{array}$ & $\begin{array}{c}90 \\
10 \\
0\end{array}$ \\
\hline 6. & $\begin{array}{l}\text { Penggunaan pupuk buatan: } \\
\text {-Urea }(\%) \\
\text {-SP-36 }(\%) \\
\text {-KCl }(\%) \\
\text {-NPK Phonska }(\%)\end{array}$ & $\begin{array}{c}100 \\
30 \\
0 \\
100\end{array}$ \\
\hline 7. & $\begin{array}{l}\text { Penggunaan pestisida: } \\
\text {-Nabati Bioprotektor }(\%) \\
\text {-Kimiawi (\%) }\end{array}$ & $\begin{array}{l}60 \\
40 \\
\end{array}$ \\
\hline 8. & $\begin{array}{l}\text { Penggunaan alat alat tanam: } \\
\text {-Jarwo transplanter }(\%) \\
\text {-Manual }(\%)\end{array}$ & $\begin{array}{l}20 \\
80\end{array}$ \\
\hline 9. & $\begin{array}{l}\text { Sistem tanam yang diterapkan: } \\
\text {-Legowo } 2: 1(\%) \\
\text {-Legowo } 4: 1(\%) \\
\text {-Jejer tegel }(\%)\end{array}$ & $\begin{array}{l}30 \\
60 \\
10 \\
\end{array}$ \\
\hline 10. & $\begin{array}{l}\text { Jarak tanam yang digunakan: } \\
-25 \times 12,5 \times 40 \mathrm{~cm}(\%) \\
-25 \times 15 \times 40 \mathrm{~cm}(\%) \\
-25 \times 25 \mathrm{~cm}(\%)\end{array}$ & $\begin{array}{l}30 \\
60 \\
10\end{array}$ \\
\hline 11. & $\begin{array}{l}\text { Jumlah bibit per lubang: } \\
-1-3 \text { bibit per lubang }(\%) \\
\text {-Lebih dari } 3 \text { bibit per lubang (\%) }\end{array}$ & $\begin{array}{l}50 \\
50 \\
\end{array}$ \\
\hline 12. & $\begin{array}{l}\text { Penggunaan alat panen: } \\
\text {-Combine harvester }(\%) \\
\text {-Threser }(\%)\end{array}$ & $\begin{array}{c}0 \\
100\end{array}$ \\
\hline
\end{tabular}




\section{Produksi dan Penerimaan Usahatani}

Implementasi inovasi teknologi Jarwo Super di Pesawaran meskipun belum semua paket teknologi diterapkan namun masih memberikan produksi dan nilai penerimaan yang signifikan (Tabel 3). Pengamatan menunjukkan bahwa produksi padi rata-rata mencapai $6.500 \mathrm{~kg} / \mathrm{ha}$ GKP.

Tabel 3.

Struktur Biaya dan Penerimaan Pada Usahatani Padi Sawah Dengan Implementasi Jarwo Super di Pesawaran, Lampung 2017

\begin{tabular}{clr}
\hline No. & \multicolumn{1}{c}{ Sarana Produksi } & Jumlah (Rp) \\
\hline A. & Biaya Sarana produksi (Rp) & 2.465 .000 \\
& 1.Benih (25 kg) & 225.000 \\
& 2.Biodekomposer (2 kg) & 160.000 \\
3.Pupuk Urea (200 kg) & 440.000 \\
4.Pupuk NPK (200 kg) & 600.000 \\
5.Pupuk kandang (1.000 kg) & 600.000 \\
6.Pupuk hayati (400bgr) & 120.000 \\
7.Bioprotektor (1 liter) & 120.000 \\
8.Herbisida (4 liter) & 120.000 \\
9.Pestisida (1 liter) & 80.000 \\
\hline B. & Biaya tenaga kerja (Rp.) & 3.300 .000 \\
1.Persemaian & 250.000 \\
2.Pengolahan tanah & 400.000 \\
3.Penanaman & 600.000 \\
4.Pengendalian Hama/Penyakit & 250.000 \\
5.Penanggulangan gulma & 250.000 \\
6.Pemupukan & 150.000 \\
7.Panen & 1.400 .000 \\
\hline Penerimaan (Rp.) & 16.250 .000 \\
Produksi rata-rata (kg) & 6.500 \\
Harga gabah (Rp/kg) & 2.500 \\
\hline C. & 2017
\end{tabular}

Sumber: data primer petani padi (diolah), 2017.

Biaya penggunaan sarana produksi meliputi benih, pupuk buatan, pupuk organik, obat-obatan dan sebagainya mencapai Rp.2.465.000. Biaya tenaga kerja meliputi pembuatan persemaian, pengolahan tanah, penanaman, pengendalian hama dan penyakit, pengendalian gulma, pemupukan, panen dan sebagainya. Biaya tenaga kerja pada usahatani padi di Pesawaran, Lampung hasil kajian sebesar Rp.3.300.000. Sedangkan produksi rata rata per hektar mencapai $6.500 \mathrm{~kg}$. Apabila harga jual rata rata gabah kering panen yang pada waktu itu mencapai Rp. $2.500 / \mathrm{kg}$, maka diperoleh penerimaan usahatani sebesar Rp. 16.250.000. Menurut Soekartawi et.al. (2011) dan Hernanto (1991) bahwa apabila nilai B/C rasio lebih besar dari 1 menunjukkan usahatani layak. Pada penerapan teknologi Jarwo Super menunjukkan nilai komparasi penerimaan terhadap biaya usahatani atau nilai $\mathrm{R} / \mathrm{C}$ rasio sebesar 2,82. Sehingga masih memberikan niai keuntungan usahatani sebesar Rp. 10.485.000 atau memberikan nilai $\mathrm{B} / \mathrm{C}$ rasio sebesar 1,82 .

\section{Pengetahuan Petani Tentang Teknologi Jarwo Super}

Pengetahuan petani padi sawah di Pesawaran, Lampung terhadap komponen teknologi budidaya padi Jarwo Super menunjukkan adanya beberapa komponen teknologi yang belum diketahui oleh para petani. Komponen teknologi tersebut terutama berkaitan dengan penggunaan alat dan mesin pertanian. Penggunaan alat tanam jarwo transplanter menunjukkan $80 \%$ petani pada kategori tidak tahu dan $10 \%$ petani pada kategori sangat tidak tahu dan hanya $10 \%$ yang mengatakan tahu.

Tingkat penggunaan alat panen padi combine harvester, $60 \%$ petani menyatakan tidak tahu, $20 \%$ sangat tidak tahu, sedangkan $20 \%$ petani menyatakan tahu penggunaan alat tersebut. Kondisi tersebut karena perubahan inovasi teknologi terutama alat dan mesin pertanian membutuhkan waktu untuk diterima oleh para petani berkaitan dengan penguasaan teknis, modal, kepemilikan alat dan mesin dan sebagainya. Untuk meningkatkan pengetahuan dan adopsi terhadap teknologi baru perlu dilakukan penyuluhan secara intensif (Abdullah et al. 2019; Andriyani, 2019; dan Viantimala et al. 2020).

Hal tersebut selain berkaitan dengan tingkat pendidikan, juga berkaitan dengan intelegensia dimana seseorang yang mempunyai intelegensia diatas rata-rata (tinggi) akan cenderung mau mencari informasi, mau mencoba, semakin cerdas, bahkan mampu mencapai tujuan sendiri serta motivasi tersendiri (Suryabrata, 2005; Sujanto, 2004).

Tabel 4 juga menunjukkan penggunaan alat dapok untuk perbenihan padi oleh 
sebagian besar petani padi $(60 \%)$ juga belum mengetahui caranya. Hal tersebut dikarenakan alat dapok sendiri merupakan rangkaian inovasi yang menyertai bagian penggunaan alat dan mesin tanam jarwo transplanter sehingga akan selaras dengan pemahaman petani.

\section{Tabel 4.}

Prosentase jumlah petani pada tingkatan skala pengetahuan teknologi Jarwo Super di Pesawaran, Lampung Tahun 2017 (\%)

\begin{tabular}{|c|c|c|c|c|}
\hline \multirow[t]{2}{*}{ Pengetahuan petani } & \multicolumn{4}{|c|}{ Skala tingkatan } \\
\hline & 1 & 2 & 3 & 4 \\
\hline $\begin{array}{l}\text { Terhadap penggunaan hand } \\
\text { traktor untuk olah tanah }\end{array}$ & 0 & 0 & 20 & 80 \\
\hline $\begin{array}{l}\text { Terhadap penggunaan ternak } \\
\text { untuk olah tanah }\end{array}$ & 0 & 0 & 50 & 50 \\
\hline $\begin{array}{l}\text { Terhadap penggunaan padi } \\
\text { varietas unggul baru }\end{array}$ & 0 & 10 & 80 & 10 \\
\hline $\begin{array}{l}\text { Terhadap Cara pembenihan } \\
\text { bibit padi menggunakan } \\
\text { dapok }\end{array}$ & 0 & 60 & 40 & 0 \\
\hline $\begin{array}{l}\text { Terhadap penggunaan pupuk } \\
\text { hayati }\end{array}$ & 0 & 30 & 60 & 10 \\
\hline $\begin{array}{l}\text { Terhadap penggunaan } \\
\text { biodekomposer }\end{array}$ & 0 & 30 & 70 & 0 \\
\hline $\begin{array}{l}\text { Penggunaan alat tanam jarwo } \\
\text { transplanter }\end{array}$ & 10 & 80 & 10 & 0 \\
\hline $\begin{array}{l}\text { Terhadap penggunaan alat } \\
\text { caplak sebagai alat bantu } \\
\text { tanam }\end{array}$ & 0 & 10 & 80 & 10 \\
\hline $\begin{array}{l}\text { Terhadap penggunaan pupuk } \\
\text { buatan pabrik }\end{array}$ & 0 & 0 & 80 & 20 \\
\hline $\begin{array}{l}\text { Terhadap penggunaan pupuk } \\
\text { kandang }\end{array}$ & 0 & 20 & 80 & 0 \\
\hline $\begin{array}{l}\text { Legowo diaplikasikan pada } \\
\text { Jarwo Super }\end{array}$ & 10 & 40 & 50 & 0 \\
\hline $\begin{array}{l}\text { Terhadap penggunaan pupuk } \\
\text { Urea }\end{array}$ & 0 & 0 & 70 & 30 \\
\hline $\begin{array}{l}\text { Terhadap penggunaan pupuk } \\
\text { SP-36 }\end{array}$ & 0 & 0 & 70 & 30 \\
\hline $\begin{array}{l}\text { Terhadap penggunaan pupuk } \\
\mathrm{KCl}\end{array}$ & 0 & 10 & 70 & 20 \\
\hline $\begin{array}{l}\text { Terhadap penggunaan pupuk } \\
\text { NPK Phonska }\end{array}$ & 0 & 0 & 70 & 30 \\
\hline $\begin{array}{l}\text { Terhadap penggunaan } \\
\text { pestisida nabati }\end{array}$ & 0 & 30 & 70 & 0 \\
\hline $\begin{array}{l}\text { Terhadap penggunaan } \\
\text { pestisida kimia }\end{array}$ & 0 & 0 & 70 & 30 \\
\hline $\begin{array}{l}\text { Terhadap penggunaan } \\
\text { herbisida }\end{array}$ & 0 & 30 & 50 & 20 \\
\hline $\begin{array}{l}\text { Terhadap penggunaan alat } \\
\text { penyiang gulma (gasrok dll) }\end{array}$ & 0 & 10 & 40 & 50 \\
\hline $\begin{array}{l}\text { Terhadap penggunaan alat } \\
\text { panen manual (sabit dll) }\end{array}$ & 0 & 30 & 10 & 60 \\
\hline $\begin{array}{l}\text { Terhadap penggunaan } \\
\text { combine harvester }\end{array}$ & 20 & 60 & 20 & 0 \\
\hline
\end{tabular}

Keterangan: $1=$ sangat tidak tahu; $2=$ tidak tahu; $3=$ tahu; 4=sangat tahu.
Apabila alat dan mesin tanamnya telah dikenal dan diketahui maka kedepan penggunaan dan cara perbenihan padi sistem dapok akan mudah diketahui. Perbenihan padi cara dapok sendiri merupakan cara perbenihan dengan menggunakan wadah tray atau tempat perbenihan sedemikian rupa sehingga padi mampu tumbuh dengan baik dan digunakan untuk penanaman padi menggunakan mesin tanam jarwo transplanter.

\section{Preferensi Petani Terhadap Teknologi Jarwo Super}

Preferensi petani menggambarkan respek atau minat petani terhadap implementasi inovasi teknologi Jarwo Super. Minat petani terhadap teknologi baru dipengaruhi oleh kemudahan penerapan dan manfaat teknologi (Wahyuni, 2019; Nurmayasari et al. 2020). Komponen teknologi Jarwo Super berupa penggunaan alat dan mesin pertanian terutama penggunaan alat dan mesin tanam jarwo transplanter serta alat pemanen combine harvester dan perbenihan sistem dapok hasilnya menunjukkan bahwa preferensi petani selaras dengan pengetahuan petani.

Tabel 5 menunjukkan preferensi petani berupa pembenihan bibit padi dengan cara menggunakan dapok menunjukkan $20 \%$ petani pada kategori sangat tidak suka, $20 \%$ petani pada kategori tidak suka dan $40 \%$ petani menyatakan agak suka dengan cara dapok tersebut. Untuk penggunaan alat tanam padi jarwo transplanter, preferensi petani terhadap penggunaan alat dan mesin tersebut menunjukkan $40 \%$ petani pada kategori tidak suka dan $50 \%$ petani menyatakan agak suka.

Sedangkan hal yang berkaitan dengan penggunaan alat panen padi combine harvester menunjukkan bahwa sekitar $10 \%$ petani berada pada kategori sangat tidak suka, $40 \%$ petani pada kategori tidak suka dan $40 \%$ petani menyatakan agak suka. Ketiga hal tersebut diduga karena adanya ketidaktahuan para petani akan alat dan mesin tersebut, dirasakan belum familiar, 
rumit, belum terbiasa, tidak sesuai dengan medan usahataninya berupa petakan sawah petani tidak luas dan berlereng, serta manfaat alat panen padi combine harvester dari aspek ekonomi.

\section{Tabel 5.}

Prosentasi jumlah petani pada berbagai tingkatan preferensinya terhadap teknologi Jarwo Super di Pesawaran, Lampung Tahun $2017(\%)$

\begin{tabular}{|c|c|c|c|c|c|}
\hline \multirow[t]{2}{*}{ Item Preferensi petani } & \multicolumn{5}{|c|}{ Skala Tingkat Kesukaan } \\
\hline & 1 & 2 & 3 & 4 & 5 \\
\hline $\begin{array}{l}\text { Penggunaan hand } \\
\text { traktor untuk olah } \\
\text { tanah }\end{array}$ & 0 & 0 & 0 & 30 & 70 \\
\hline $\begin{array}{l}\text { Penggunaan ternak } \\
\text { untuk olah tanah }\end{array}$ & 0 & 10 & 50 & 30 & 10 \\
\hline $\begin{array}{l}\text { Penggunaan padi } \\
\text { varietas unggul baru }\end{array}$ & 0 & 0 & 10 & 90 & 0 \\
\hline $\begin{array}{l}\text { Cara pembenihan bibit } \\
\text { padi menggunakan } \\
\text { dapok }\end{array}$ & 20 & 20 & 40 & 20 & 0 \\
\hline $\begin{array}{l}\text { Penggunaan pupuk } \\
\text { hayati }\end{array}$ & 0 & 0 & 10 & 90 & 0 \\
\hline $\begin{array}{l}\text { Penggunaan } \\
\text { biodekomposer }\end{array}$ & 0 & 0 & 20 & 60 & 20 \\
\hline $\begin{array}{l}\text { Penggunaan alat tanam } \\
\text { jarwo transplanter }\end{array}$ & 0 & 40 & 50 & 10 & 0 \\
\hline $\begin{array}{l}\text { Penggunaan alat } \\
\text { caplak sebagai alat } \\
\text { bantu tanam }\end{array}$ & 0 & 0 & 20 & 70 & 10 \\
\hline $\begin{array}{l}\text { Penggunaan pupuk } \\
\text { buatan pabrik }\end{array}$ & 0 & 0 & 0 & 50 & 50 \\
\hline $\begin{array}{l}\text { Penggunaan pupuk } \\
\text { kandang }\end{array}$ & 0 & 0 & 60 & 40 & 0 \\
\hline $\begin{array}{l}\text { Penggunaan pupuk } \\
\text { kompos }\end{array}$ & 0 & 0 & 70 & 30 & 0 \\
\hline $\begin{array}{l}\text { Preferensi terhadap } \\
\text { penggunaan pupuk } \\
\text { Urea }\end{array}$ & 0 & 0 & 0 & 70 & 30 \\
\hline $\begin{array}{l}\text { Penggunaan pupuk } \\
\text { SP-36 }\end{array}$ & 0 & 0 & 20 & 40 & 40 \\
\hline $\begin{array}{l}\text { Penggunaan pupuk } \\
\mathrm{KCl}\end{array}$ & 0 & 10 & 50 & 20 & 20 \\
\hline $\begin{array}{l}\text { Penggunaan pupuk } \\
\text { NPK Phonska }\end{array}$ & 0 & 0 & 0 & 60 & 40 \\
\hline $\begin{array}{l}\text { Penggunaan pestisida } \\
\text { nabati }\end{array}$ & 0 & 0 & 100 & 0 & 0 \\
\hline $\begin{array}{l}\text { Penggunaan pestisida } \\
\text { kimia }\end{array}$ & 0 & 0 & 10 & 60 & 30 \\
\hline Penggunaan herbisida & 0 & 10 & 30 & 20 & 40 \\
\hline $\begin{array}{l}\text { Penggunaan alat } \\
\text { penyiang gulma } \\
\text { (gasrok dll) }\end{array}$ & 0 & 0 & 0 & 40 & 60 \\
\hline $\begin{array}{l}\text { Penggunaan alat panen } \\
\text { manual (sabit dll) }\end{array}$ & 0 & 10 & 0 & 40 & 50 \\
\hline $\begin{array}{l}\text { Penggunaan combine } \\
\text { harvester }\end{array}$ & 10 & 40 & 40 & 10 & 0 \\
\hline $\begin{aligned} \text { eterangan: } 1=\text { sang } \\
3=\text { kura } \\
\text { suka. }\end{aligned}$ & $0^{\circ}$ & & 1 & & \\
\hline
\end{tabular}

Komponen budidaya berupa penggunaan ternak untuk olah tanah menunjukkan $10 \%$ petani pada preferensi kategori sangat tidak suka, $50 \%$ petani pada preferensi kategori agak suka. Penggunaan pestisida nabati menunjukkan $100 \%$ petani pada kategori agak suka. Penggunaan herbisida menunjukkan $10 \%$ petani pada preferensi kategori tidak suka, 30\% petani pada preferensi kategori agak suka. Sedangkan penggunaan pupuk buatan $\mathrm{KCl}$ menunjukkan $10 \%$ petani pada preferensi kategori tidak suka, $50 \%$ petani pada kategori agak suka. Kondisi tersebut dikarenakan ketersediaan sarana produksi pupuk yang tersebut diatas keberadaanya agak jarang tersedia dengan kualitas yang diinginkan petani (kualitas bagus) termasuk keberadaan tenaga kerja ternak sebagai prasarana pengolahan tanah cukup jarang tersedia di lokasi usahatani. Mendatang pergeseran penggunaan alat dan mesin akan semakin intensif terjadi.

Meskipun demikian terhadap evaluasi komponen inovasi teknologi Jarwo Super tersebut maka tanggapan petani menunjukkan bahwa kebaharuan inovasi tersebut berupa adanya penekanan penggunaan saprodi bersifat organik (biodekomposer, pestisida nabati, pupuk organik) yang mana petani cenderung menerima sesuai pemikiran logisnya. Bahkan menurut para petani apabila komponen tersebut diterapkan sesuai prosedur maka inovasi teknologi jajar legowo super sangat prospektif meningkatkan produksi dan pendapatan usahatani padi.

\section{KESIMPULAN}

Penerapan teknologi Jarwo Super pada usahatai padi sawah di Pesawaran, Lampung menunjukkan bahwa belum semua petani melakukan penerapan dengan cara teknologi seutuhnya sesuai rekomendasi. Penerapan teknologi Jarwo Super memberikan hasil produksi padi yang cukup bervariasi 4-8 ton/ha dengan rata-rata produksi 6,5 ton/ha GKP dan 
menguntungkan sehingga layak diusahakan. Preferensi petani padi terhadap inovasi teknologi Jarwo Super cukup baik dengan tingkat pengetahuan terhadap inovasi tersebut cukup tinggi. Tanggapan petani bahwa kebaharuan inovasi Jarwo Super adalah adanya penekanan penggunaan saprodi bersifat organik (biodekomposer, pestisida nabati, pupuk organik). Menurut petani apabila diterapkan sesuai prosedur maka inovasi teknologi Jajar Legowo Super (Jarwo Super) sangat prospektif meningkatkan produksi dan pendapatan usahatani padi. Usahatani dengan teknologi Jarwo Super dimasa mendatang perlu intensif disebar luaskan pada masyarakat petani.

\section{DAFTAR PUSTAKA}

Abdullah, A., Jamila, J., Amidah A., Amrullah, A., Syahdar, B., dan Ibrahim, H. (2019). Identifikasi Aplikasi Penggunaan Cyber Extension Sebagai Sumber Informasi Penyuluh dalam Adopsi Teknologi Pakan. Suluh Pembangunan : Journal of Extension and Development. 1 (2): 109-114.

Adriyani, F.A. (2019). Pemanfaatan Cyber Extension Sebagai Media Diseminasi Inovasi Pertanian oleh Penyuluh Pertanian di Provinsi Lampung. Suluh Pembangunan : Journal of Extension and Development. 1(1):: 17.

Badan Litbang Pertanian. (2016a). Budidaya Padi Jajar Legowo Super. Petunjuk Teknis. Badan Penelitian dan Pengembangan Pertanian, Kementerian Pertanian, Jakarta.

Badan Litbang Pertanian. (2016b). Teknologi Jajar Legowo Super untuk Mendongkrak Produktivitas Padi. http://www.litbang.pertanian.go.id/ber ita/one/2574/ (medio 20 April 2016).

Dinas Pertanian Tanaman Pangan dan Hortikultura Propinsi Lampung. (2017). Laporan Kegiatan Dinas
Pertanian Tanaman Pangan dan Hortikultura Propinsi Lampung. Bandar Lampung.

Hernanto, F. (1991). Ilmu Usahatani. Penebar Swadaya.

Matualage, A. (2010). Keefektifan Pembelajaran sosial Kearifan Lokal Budidaya Ubi Jalar Di Kalangan Suku Arfak Kabupaten Manokwari. Tesis: Program Studi Penyuluhan dan Komunikasi Pembangunan. Sekolah Pascasarjana Universitas Gadjah Mada, Yogyakarta.

Mc.Elreath, R. (2004). Social Learning and the Maintenance of Cultural Variation: An Evolutionary Model and Data from East Africa. Journal American Anthropologist, Vol.106, Juni 2004. Issue 2, pp.308-321.

Nazir, M. (2005). Metode Penelitian. Jakarta: Penerbit Ghalia.

Nurmayasari, I., Viantimala, B., Gultom, D.T., Yanfika, H. dan Mutolib, A. (2020). Partisipasi dan Kepuasan Petani Terhadap Kinerja Penyuluh Pertanian di Kecamatan Palas Kabupaten Lampung Selatan. MIMBAR AGRIBISNIS: Jurnal Pemikiran Masyarakat Ilmiah Berwawasan Agribisnis. 6(1): 448-459.

Pailis, F.G. (2006). The role of culture in farmer learning and technology adoption: A case study of farmer field schools among rice farmers in central Luzon, Philippines. Journal Agriculture and Human Values (2006) 23:491-500.

Soekartawi, A., Soehardjo., John L. D., dan Hardaker, J.B. (2011). Ilmu Usahatani dan Penelitian untuk Pengembangan Petani Kecil. UI Press.

Subin, I., Charlotte, H., Mason., and Houston. M.B. (2007). Does innate consumer innovativeness relate to new product/service adoption behavior? The intervening role of social learning via vicarious innovativeness. Journal of the Academy of Marketing Science 
(2007) 35:63-75. Pubhlised on line 3 February 2007.

Sujanto A. (2004). Psikologi Umum. Jakarta: Bumi Aksara.

Suryabrata, S. (2005). Psikologi Pendidikan. Jakarta: PT. Raja Grafindo Persada.

Utami, B.N. (2009). Proses Social Learning di Kalangan Petani Dalam Kegiatan Pengolahan Pupuk Organik Di Kecamatan Jetis, Kabupaten Bantul. Tesis: Program Studi Penyuluhan dan Komunikasi Pembangunan. Sekolah Pascasarjana Universitas Gadjah Mada, Yogyakarta.
Viantimala, B., Yanfika, H., Mutolib, A., Listiana, L. dan Effendi, I. (2020). Kinerja Penyuluh dan Partisipasi Petani Dalam Kegiatan Penyuluhan Pertanian Di Kecamatan Kotagajah Kabupaten Lampung Tengah. Journal of Food System and Agribusiness. 4 (1): 9-16.

Wahyuni, S. (2019). Hubungan Karakteristik Inovasi dan Pola Komunikasi Terhadap Keberlanjutan Penerapan Teknologi Padi Salibu di Kabupaten Tanah Datar. Suluh Pembangunan : Journal of Extension and Development. 1 (2):: 72-80. 